\title{
Tras bambalinas: museografía y proyección de imaginarios nacionales en las Exposiciones Históricas (Madrid 1892) ${ }^{1}$
}

\section{Behind the scenes: museography and projection of national imaginaries in the Historical Exhibitions (Madrid 1892)}

\author{
DOI:https://doi.org/10.25100/hye.v16i54.9906 \\ Artículo recibido: 25-09-2018 Artículo aceptado: 05-05-2019
}

\section{Carmen Cecilia Muñoz Burbano}

Licenciada en Filosofía de la Universidad del Valle, realizó estudios de Artes Plásticas en el Instituto Departamental de Bellas Artes, es Especialista en Conservación de material etnográfico por la Universidad Complutense de Madrid (España) y Magister en Historia Contemporánea por la Universidad Complutense de Madrid (España), ademas de candidata a doctor en el programa de doctorado Ingeniería Agraria, Alimentaria, Forestal y de Desarrollo Rural Sostenible de la Universidad de Córdoba (España).

Universidad del Valle, Colombia.

Correo electrónico: Carmen.munoz@correounivalle.edu.co

ORCID: No tiene

Forma de citar este artículo: Muñoz Burbano, Carmen Cecilia y Paula Revenga Domínguez. "Tras bambalinas: museografía y proyección de imaginarios nacionales en las Exposiciones Históricas (Madrid 1892)". Historia y Espacio, vol. 16 n ${ }^{\circ} 54$ (2020): 103-136. Doi.org/10.25100/hye.v16i54.9906

\footnotetext{
Artículo Tipo 2: de reflexión. 1 Hace parte de la tesis doctoral España y la proyección de una imagen nacional en época de crisis. Historia, raza y religión en las Exposiciones Históricas del IV Centenario del descubrimiento de América (1892), inscrita en el programa de doctorado Ingeniería Agraria, Alimentaria, Forestal y de Desarrollo Rural Sostenible de la Universidad de Córdoba (España), bajo la dirección de la Dra. Paula Revenga Domínguez, docente del departamento de Historia del Arte, Arqueología y Música.
} 
Tras bambalinas: museografía y proyección de imaginarios nacionales...

Carmen Cecilia Muñoz Burbano - Paula Revenga Domínguez

\section{Paula Revenga Domínguez}

Es Licenciada en Geografía e Historia, especialidad de Historia del Arte, por la Universidad Complutense de Madrid (UCM), España, premio extraordinario de licenciatura por la UCM. A nivel Postgradual cuenta con un Doctorado en Historia del Arte por la Universidad Complutense de Madrid, premio extraordinario de doctorado por la UCM.

Universidad de Córdoba, España.

Correo electrónico: paredom@gmail.com

ORCID: 0000-0003-0119-978X

\section{Resumen}

Proponemos una reflexión sobre la proyección de imaginarios nacionales, a uno y otro lado del Atlántico, a partir del análisis de los discursos museográficos desplegados por Portugal y Colombia en las Exposiciones Históricas que tuvieron lugar en Madrid, en 1892, en el marco de la celebración del cuarto centenario del descubrimiento de América. El primero, un país ibérico en crisis que, recurriendo a un pasado idealizado, despliega narrativas en función de su identidad marítima, convertida en proyección atlántica y elemento central de su configuración como Estado moderno. La segunda, una recién independizada nación americana en busca de elementos identitarios que la diferenciaran de sus vecinas y a la vez contribuyeran a ubicarla en el concierto de la modernidad. En este caso, son las antigüedades indígenas las que le permiten demostrar los grados de civilización alcanzados por sus antiguos pobladores que, sin embargo, no serán incluidos en la historia nacional. A ello contribuirá la teoría del catastrofismo, que las considera desaparecidas, y la configuración de lo hispánico como momento fundacional. Estos casos, aparentemente distantes, hacen parte no solo de una historia trasatlántica, sino de historias conectadas a través de una "situación de contacto" de gran relevancia en la proyección de imaginarios nacionales, como fue la celebración centenarista.

Palabras clave: centenarios, museografía, identidad nacional, Colombia, Portugal, siglo XIX.

\section{Abstract}

We propose a reflection on the projection of national imaginaries, on both sides of the Atlantic, from the analysis of the museum discourses deployed by Portugal and Colombia in the Historical Exhibitions that took place in Madrid, in 1892, as part of the celebration of the fourth centenary of the discovery of America. The first, an Iberian country in crisis that, resorting to an idealized past, displays narratives based on its maritime identity, converted into Atlantic projection and central element of its configuration as a modern state. The second, a newly independent American nation in search of identity elements that would differentiate it from its neighbors and at the same time contribute to the concert of modernity. In this 
case, it is the indigenous antiquities that allow it to demonstrate the degrees of civilization achieved by its former inhabitants that, however, will not be included in national history. These seemingly distant cases are part not only of a transatlantic story, but of stories connected through a "contact situation" of great relevance in the projection of national imaginaries, as was the centenarist celebration.

Keywords: centenarians, museography, national identity, Colombia, Portugal, 19 th century. 


\section{Carmen Cecilia Muñoz Burbano - Paula Revenga Domínguez}

\section{Tras bambalinas: museografía y proyección de imaginarios nacionales en las Exposiciones Históricas (Madrid 1892)}

\section{Introducción}

En el marco de la conmemoración del cuarto centenario del descubrimiento de América, tres naciones asumen el protagonismo de su celebración: Italia, por ser la cuna de Cristóbal Colón; España, por su participación decisiva en el proyecto colonizador y Estados Unidos, por considerar que a través del genovés llegó la civilización al territorio americano. En este contexto, se llevaron a cabo una serie de eventos, entre los que se destacaron las exposiciones de carácter internacional que cada una de ellas programó: la Ítalo-Americana (Génova, 1892); la Histórico-Americana y la Histórico-Europea (Madrid, 1892), referidas como Exposiciones Históricas y la Universal Colombina de Chicago (1893).

Este artículo propone una reflexión sobre la participación de Portugal y Colombia en las Exposiciones Históricas que tuvieron lugar en Madrid. Desde una y otra orilla y de distinta manera, estos casos evidencian la estrecha relación entre museografía y representación de imaginarios en torno a las formas de historiar el pasado, en un momento clave de la construcción de identidades nacionales, como fue el contexto finisecular. El primero, un país ibérico en crisis que, recurriendo a un pasado idealizado, desplegó narrativas en función de su identidad marítima, convertida en proyección atlántica y elemento central de su configuración como Estado moderno. La segunda, una recién independizada nación americana en busca de elementos identitarios que la diferenciaran de sus vecinas y a la vez contribuyeran a ubicarla en el concierto de la modernidad. En este caso, son las antigüedades indígenas las que le permiten demostrar los grados de civilización alcanzados por sus antiguos pobladores que, sin embargo, no serán incluidos en la historia nacional. A ello contribuyó la teoría del catastrofismo, que las consideró desaparecidas, y la configuración de lo hispánico como momento fundacional. Estos casos, aparentemente distantes, hacen parte no sólo de una historia trasatlántica, sino de historias conectadas a través de una "situación de contacto" de gran relevancia en la proyección de imaginarios nacionales, como fue la celebración centenarista. 
Nos proponemos, pues, identificar y analizar la matriz discursiva que subyace tras las museografías desplegadas en las salas que les fueron asignadas a Portugal y Colombia en las Exposiciones Históricas. El primer apartado ofrece un balance del estado de la cuestión respecto a investigaciones sobre dichas exposiciones, a la vez que presenta las principales perspectivas teóricas y metodológicas empleadas en el presente estudio. El segundo aborda el concepto expositivo que las guio, a partir de dos aspectos: el mobiliario y los criterios de instalación. Los dos últimos analizan los contextos históricos y políticos que promovieron la participación de Portugal y Colombia, muy necesarios a la hora de intentar entender las complejas maneras de abordar la representación de la nación mediante un discurso visual.

\section{Marco teórico-metodológico}

Cada vez son más numerosos los estudios que abordan aspectos relacionados con las Exposiciones Históricas que tuvieron lugar en Madrid en 1892. Como en casi toda temática, en primer lugar encontramos acercamientos que las inscriben en problemáticas más amplias, como es el caso de las exposiciones con énfasis americanista que tuvieron lugar en España a lo largo del siglo XIX (Martínez y Verde, 2005). Luego vendrán estudios que abordan casos puntuales de participación, tal es el caso de México (Ramírez, 2009; Mendoza, 2016), Colombia (Martínez, 2000; Muñoz, 2012) o Portugal (Pimienta-Silva (2013). Además, están los análisis en perspectiva comparada, en auge creciente, sobre todo para el ámbito hispanoamericano (Bedoya, 2016; Cubero, 2016 y 2018; Muñoz, 2013; Hoth, 2016), y los que abordan su inscripción en un contexto más global, como el imperialismo de fin de siglo (Valverde, 2011, 2015, 2016). También hay que tener en cuenta las recientes exposiciones y publicaciones que sobre estos eventos ha realizado el Museo Arqueológico Nacional de España (2016 y 2018) y la digitalización que ha hecho de los fondos correspondientes a ellas.

Desde el punto de vista teórico, el análisis se aborda desde una mirada interdisciplinar, en la que confluyen enfoques propuestos desde la museología y la historia cultural, sobre todo, además de los referentes al nacionalismo y al análisis del discurso. Así, el punto de partida será el término "concepto expositivo", propuesto por Rico ${ }^{2}$, que hace referencia a los contextos históricos específicos en los que se inscriben las exposiciones, y que permiten identificar

2 Juan Carlos Rico, Manual práctico de museología, museografía y técnicas expositivas (Madrid: Sílex Ediciones, 2006), 27-28. 
los giros significativos en relación con las maneras de ver y exponer “algo". Como complemento a esta perspectiva, Freestone ${ }^{3}$ plantea que los eventos expositivos constituyen lentes de observación privilegiada del mundo moderno, pues en ellos confluyen intereses de toda índole, especialmente de carácter político e ideológico, que son los que pueden llevar a explorar el carácter prismático de sus manifestaciones. Frisch ${ }^{4}$, como semiólogo, señala la necesidad de analizar dichos proyectos desde la construcción de sentido, con el fin de identificar los signos y significantes presentes en su naturaleza. Chakrabarty ${ }^{5}$, por su parte, puntualiza en la necesidad de identificar la "matriz discursiva" que subyace en todo discurso, incluido el museográfico. Y Benedict ${ }^{6}$ propone el análisis del complejo entramado de reacciones entre identidades nacionales y discursos expositivos.

Dado que estos certámenes constituyen espacios de representación por excelencia, los postulados de la historia cultural ${ }^{7}$ facilitan el análisis de las diversas prácticas y actores que se dieron cita en las Exposiciones Históricas, así como el de las representaciones a través de las cuales se escenificaron sus imaginarios nacionales. Al análisis de estos aspectos también contribuyen estudios sobre nacionalismos como los de Smith ${ }^{8}$, Hobsbawm ${ }^{9}$ y White ${ }^{10}$,

3 Robert Freestone y Marco Amati (Eds.), Exhibitions and the Development of Modern Planning Culture (London: Ashgate Publishing Ltd., 2014).

4 Michael H. Frisch, "El prisma del pasado en el cambio del siglo: uso de las ferias mundiales. La exposición panamericana de 1901 como estudio de un caso concreto", Studia Historica. Historia Contemporánea, N. ${ }^{0} 16$ (Salamanca, 1998): 129.

5 Dispesh Chakrabarty, Al margen de Europa. Pensamiento postcolonial y diferencia histórica (Barcelona: Tusquets Editores, 2008).

6 Burton Benedict, "International Exhibitions and National Identity", Anthropology Today Vol. 7, N. ${ }^{\circ}$ 3, (jun., 1991): 5-9.

7 Peter Burke, ¿Qué es la historia cultural? (Barcelona: Paidós, 2006).

8 Anthony Smith y Olaf Bernárdez, Nacionalismo: teoría, ideología, historia (Madrid: Alianza Editorial, 2004).

9 Eric Hobsbawm, “Introducción: la invención de la tradición”, en La invención de la tradición (Barcelona: Editorial Crítica, 2002), 7-21.

${ }^{10}$ Hayden White, Metahistoria: la imaginación histórica en la Europa del siglo XIX (México: Fondo de Cultura Económica, 1992). 
para el caso europeo; y los de Quijada ${ }^{11}$, Norambuena ${ }^{12}$ y Earle ${ }^{13}$, para el ámbito hispanoamericano. Aportes que ayudan a entender los procesos de construcción nacional, no como formaciones políticas o ideológicas estáticas, sino como complejos entramados, inmersos en grandes debates y con dinámicas propias. Y la noción de "historia conectada", propuesta por Bertrand ${ }^{14}$, permite ubicar nuestros casos, aparentemente distantes, inmersos en "una situación de contacto", como el contexto centenarista, en sentido amplio, y las Exposiciones Históricas, de manera puntual. A estas últimas, les debemos un contacto, de carácter histórico y cultural, entre la mayor parte de las naciones americanas y algunas europeas, en especial las peninsulares, bajo un objetivo común: proyectar unos imaginarios respecto a sus pasados, teniendo como eje el hecho colombino.

Por otra parte, el estudio de temas relacionados con las exposiciones, sobre todo las de carácter internacional, trae consigo un gran reto metodológico, el de enfrentarse a la gran cantidad de documentación que generan, desde decretos, correspondencia diplomática, catálogos, fotografías, hasta reseñas en prensa y revistas especializadas, entre otras tantas. Testimonios del esfuerzo que implicó el proceso de selección y clasificación de una serie de objetos que, a través de un discurso museográfico, serán los responsables de escenificar "un aspecto de la nación" que, de una u otra manera, guarda relación con la proyección de imaginarios y la construcción de identidades nacionales.

\section{Naturaleza y concepto expositivo de las Exposiciones Históricas}

En España, los preparativos de la celebración centenarista iniciaron en 1888 , momento en el que se proyectó llevar a cabo una exposición de carácter internacional, diacrónico y comparativo, ya que se pretendía mostrar no solo los grados de civilización que presentaban los pueblos americanos a la

${ }^{11}$ Mónica Quijada, “Ancestros, ciudadanos, piezas de museo. Francisco P. Moreno y la articulación del indígena en la construcción nacional argentina”, Estudios Interdisciplinarios de América Latina y el Caribe, Vol. IX, N. ${ }^{\circ} 2$ (1998).

${ }^{12}$ Carmen Norambuena, "Imaginarios nacionales latinoamericanos en el siglo XIX", Historia Unisinos Vol. 10, N. 2 (2006): 121-132.

13 Rebecca Earle, "Monumentos y museos: la nacionalización del pasado precolombino en la Hispanoamérica decimonónica, en Beatriz González Stephan y Jens Andermann, (eds.), Galerías del progreso: museos, exposiciones y cultura visual en América Latina (Rosario: Beatriz Viterbo Editora, 2006), 27-56.

${ }^{14}$ Romain Bertrand, “Historia global, historias conectadas: ¿un giro historiográfico?”, Prohistoria: historia, políticas de la historia, N. 24 (2015): 3-20. 
llegada a sus territorios, sino también los logros que habían alcanzado tras tres siglos del dominio peninsular ${ }^{15}$. Sin embargo, las implicaciones logísticas y la escasa respuesta de las naciones americanas, sobre todo en lo relativo al segundo aspecto, obligaron en 1891 a cambiar la naturaleza del proyecto inicial, y a contemplar la realización de dos exposiciones internacionales, pero, sincrónicas y enmarcadas en la época del descubrimiento, especialmente los siglos XVI y XVII ${ }^{16}$.

Por ello, España hizo dos llamados. El primero, a todas sus provincias y colonias (Cuba, Puerto Rico y Filipinas), además de Portugal, para que concurrieran con manifestaciones del trabajo y la cultura peninsular, desde los tiempos de la restauración visigoda hasta la segunda mitad del siglo XVI; así como al resto de naciones europeas para que participaran con lo más selecto de su producción artística a la que denominó Exposición Histórico-Europea. El segundo, a las recién independizadas naciones americanas para que ofrecieran un panorama del "estado en que se hallaban por los días del descubrimiento [...] agrupando al efecto cuantos objetos concurran a dar idea del origen y progreso de su relativa cultura ${ }^{17}$ en la nombrada Exposición Histórico-Americana.

Las Exposiciones Históricas abrieron sus puertas en noviembre de 1892, en el Palacio de Biblioteca y Museos Nacionales de Madrid, inaugurado para la ocasión, y se convirtieron en ocasión única de ver reunido casi todo lo que se conserva diseminado por el mundo ${ }^{18}$. Inscritas en una escala global, equivalían a un viaje por ambos continentes para conocer los tesoros de la Edad Media y de las culturas precolombinas. Del lado americano acudió la mayor parte de sus naciones, incluidos Estados Unidos como nueva potencia imperial; del europeo, España como anfitriona y Portugal en calidad de invitada especial; además de Dinamarca, Suecia, Noruega, Alemania, Austria y Francia. Por tanto, estos eventos tienen una importancia política, cultural y científica sin precedentes en el contexto decimonónico.

Desde el punto de vista de la reglamentación que las cobijó, si bien es cierto que no se acogió plenamente, permite contextualizar los principales aspectos de su naturaleza. Para empezar, desde el punto de vista político, y en contravía del reglamento que estipuló una división cronológica basada en la técnica de los artefactos, los países participantes optaron por acudir a nombre propio,

\footnotetext{
15 “Real Decreto de 28 de febrero de 1888”, Gaceta de Madrid, febrero 291888.

16 "Real Decreto de 9 de enero de 1891", Gaceta de Madrid, enero 10, 1891.

17 Ibíd.

${ }^{18}$ La Época, Madrid, noviembre 28, 1892, 1.
} 
disponiendo cada cual de sus colecciones y decidiendo la forma en que debían ser expuestas. Es decir, tras cada instalación hay un trasfondo ideológico permeado por el auge finisecular de los nacionalismos y la búsqueda de elementos identitarios. En este sentido, ocupó un papel clave la manera como asumieron sus respectivos pasados y las connotaciones que les atribuyeron, así como el momento fundacional que eligieron para imaginar la nación.

La Junta del Centenario, de la cual dependían, creó cuatro secciones presididas por los ministros de Estado, Fomento, Ultramar y el capitán Joaquín Jovellar, respectivamente. La primera asumió la organización de la HistóricoAmericana, quedó en manos del director del Museo Arqueológico Nacional, Juan de Dios de la Rada y Delgado y una comisión auxiliar constituida, en su mayor parte, por personal de dicho museo ${ }^{19}$. La segunda se hizo responsable de la Histórico-Europea, bajo el mando de Fidel Fita Colomé, un especialista en historia eclesiástica y miembro de la Academia de Historia, quien contó con el apoyo del arqueólogo e historiador Juan Catalina y García ${ }^{20}$. Entre sus funciones estuvieron reglamentar la clasificación de objetos, elaborar los catálogos, escoger los jurados y premios y atender los asuntos administrativos.

El edificio que las albergó, construido con material proveniente de la fábrica de Altos Hornos de Bilbao, contaba con un amplio programa iconográfico en sus fachadas, tanto del Paseo de Recoletos como de la calle de Serrano, y una decoración basada en el estilo griego, más ó menos influido por corrientes modernas ${ }^{21}$, además de un entresuelo; una planta baja que alojó a la HistóricoAmericana, con 46 espacios, sin contar vestíbulos y escaleras, y la principal en la que se instaló la Histórico-Europea, con 49 áreas, dos escaleras principales, nueve patios, cinco de los cuales estaban cubiertos y se adaptaron como salas. Cada una contaba con 27 salones para exposición, distribuidos de forma "casi idéntica”, solo con una u otra variación en la división de algunos de ellos.

El Día publicó un "Suplemento-guía de las Exposiciones Históricas del Centenario" que incluyó reseñas, ilustraciones y un plano. La reseña de la Histórico-Europea corrió a cargo de Narciso Sentenach, quien describió, a grandes rasgos, las salas asignadas a la Biblioteca Nacional, los museos Arqueológico Nacional, de Artillería y provinciales; las diputaciones, ayuntamientos, comisiones de monumentos, iglesias y catedrales, la casa real, las bibliotecas de la Universidad Central, los archivos Histórico Nacional y

\footnotetext{
${ }^{19}$ El Centenario, Tomo I, Madrid, 1892: 285-292.

${ }^{20}$ El Centenario, Tomo III, Madrid, 1892: 139-144.

${ }^{21}$ El Correo Español, Madrid, octubre 31, 1892, 2.
} 
General Central de Alcalá de Henares, a colecciones particulares, a Austria, así como a Francia y sus colonias ${ }^{22}$. La de la Histórico-Americana, a la pluma de José Ramón Mélida quien, apoyado en un esquema, basado en el plano oficial (Figura N. ${ }^{\circ}$ ), dio cuenta de los espacios asignados a las naciones hispanoamericanas y a Estados Unidos, a España (sección de minerales, de objetos pre y post colombinos y de documentos), a Portugal, así como a Dinamarca, Suecia, Noruega y Alemania. Aunque no es nuestro propósito analizar esta distribución, si queremos destacar que causó desconcierto y confusión, hasta el punto de que se cuestionó la denominación de las exposiciones.(Ver figura 01)

22 "Suplemento-guía de las Exposiciones Históricas del Centenario",El Día, Madrid, noviembre $10,1892,2$. 
Figura N. ${ }^{\circ}$ 1: Planta de la Exposición Histórico-Americana

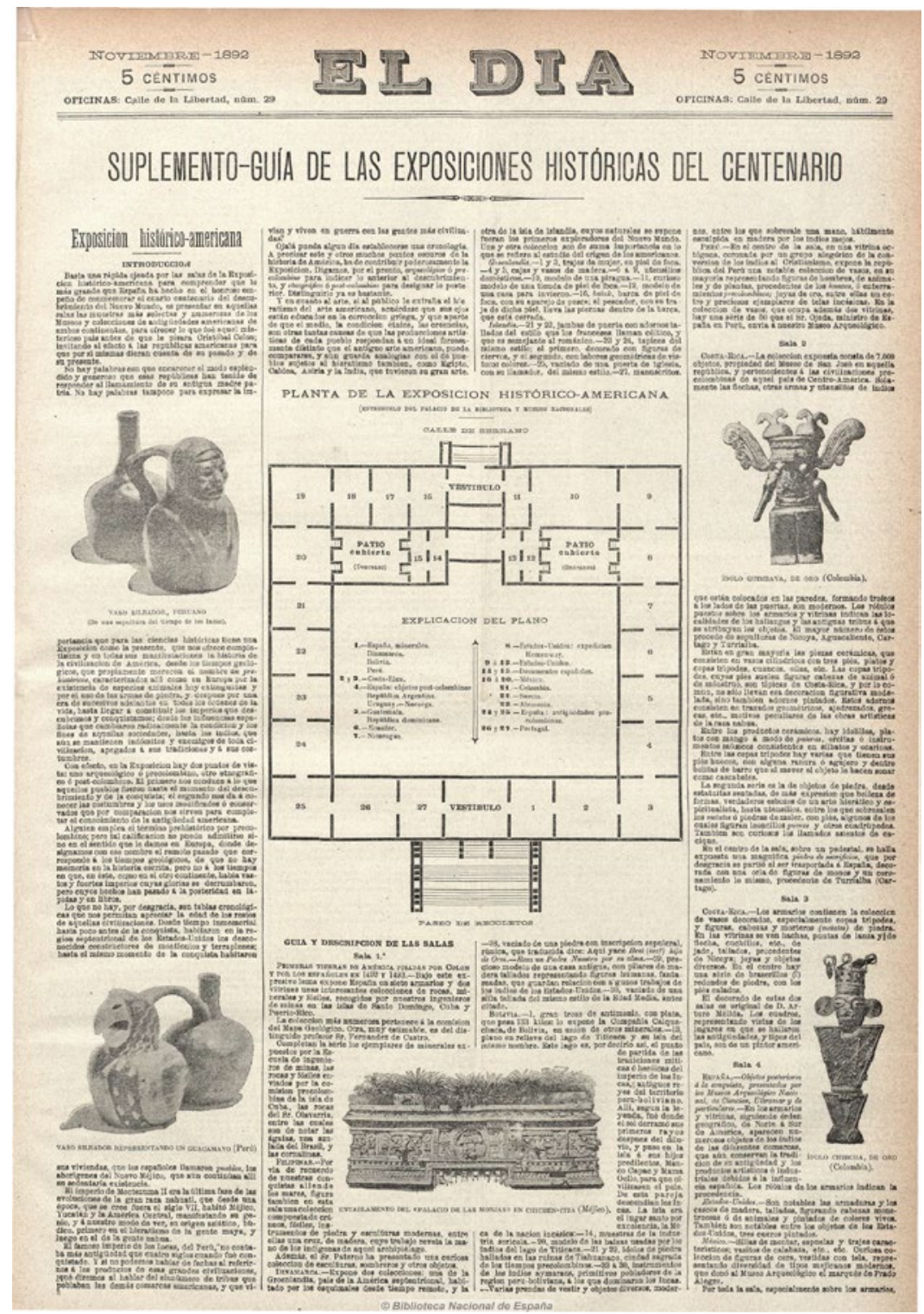

Fuente: “Suplemento-guía de las Exposiciones Históricas del Centenario", El Día, Madrid, noviembre 10, 1892, 2. http://hemerotecadigital.bne.es/issue.vm?id=0002320318, 1, consultado 3 de junio de 2018. 
Entre los elementos que caracterizan el concepto expositivo en el siglo XIX, considerado "de los museos públicos", están los criterios de clasificación propuestos por el enciclopedismo, histórico o iconográfico, el uso de un mobiliario elaborado de forma expresa y la toma de conciencia del creciente y diverso público que visitaba las instituciones museísticas. Hacia mediados del siglo, el South Kensington Museum de Londres (hoy The Victoria and Albert Museum) estableció un conjunto de pautas en torno a las temáticas, el carácter de las colecciones, el montaje y la decoración de las salas, y fomentaba la ambientación "teatralizada”. De otra parte, y recogiendo el legado de la Ilustración, la cronología y la disposición geográfica constituían una regla de oro a la hora de ordenar, agrupar y clasificar material de carácter científico, y el aspecto pedagógico empezó a tener preponderancia sobre el disfrute meramente estético. Con el arribo de la revolución industrial y el auge de las ferias mundiales, se impusieron nuevas formas de representación visual que se conjugaron con los criterios científicos, artísticos, arqueológicos y etnográficos; los museos empezaron a especializarse y la tipología de lo expuesto definía la pauta de la instalación ${ }^{23}$.

España no fue ajena a estas tendencias, el Museo Arqueológico Nacional ${ }^{24}$ y la colección del marqués de Cerralbo ${ }^{25}$ eran un ejemplo de las influencias que, a través de la literatura especializada y los viajes de la elite letrada, llegaban no sólo a las instituciones museísticas, sino a los coleccionistas particulares. Las Exposiciones Históricas, inmersas en este contexto, al concebir la época del descubrimiento como un principio fijo y determinado [y] á este trascendental suceso habrá $[n]$ necesariamente de referirse ${ }^{26}$, consideraban fundamental la aplicación del criterio de clasificación cronológico. Así, la Histórico-Americana debió mostrar material procedente de la protohistoria americana, los tiempos conocidamente históricos, el trascendental descubrimiento de América por Colón y los españoles, hasta las conquistas de mediados del siglo

${ }^{23}$ Cecilia Casas, "El Museo Cerralbo, una colección personal, una instalación de su tiempo 1893-1922”, en Museos de ayer. Museografías históricas en Europa (Madrid: Ministerio de Educación, Cultura y Deporte, Subdirección General de Documentación y Publicaciones, 2017): 25-26.

${ }^{24}$ Virginia Salve et ál., "Espacios y objetos a través del tiempo: Museografía histórica de las salas del Museo Arqueológico Nacional”, Boletín del Museo Arqueológico Nacional, N. 32 (2014): 60-66.

${ }^{25}$ Casas, "El Museo", 2.

${ }^{26}$ El Centenario, Tomo II, Madrid, 1892: 140. 
XVII y, la Histórico-Europea, estuvo ceñida a los siglos XVI y XVII ${ }^{27}$. Con estos parámetros, la primera puso el acento en lo arqueológico, lo etnográfico y, en menor medida, en muestras provenientes de la naturaleza, y asumió el criterio de clasificación científica que atendía a la técnica de los artefactos. La segunda, por su parte, contempló los criterios de "naturaleza y calidad", el primero aludía a las dos grandes divisiones de Bellas Artes e industrias artísticas, el segundo al carácter industrial o artístico.

\section{El mobiliario: de cosa principal a importancia secundaria}

Entre las tipologías de mobiliario más utilizadas en las Exposiciones Históricas estuvieron las vitrinas, de altura variable y cerradas con vidrios, cuyo origen fue en el siglo XVI, cuando fueron concebidas como la última valla de protección ${ }^{28}$; los escaparates, muebles de lujo genuinamente españoles, cuyo esplendor fue en el primer Barroco y fueron recuperados más tarde por el historicismo para exhibir objetos preciosos, suntuarios o de devoción ${ }^{29}$; los armarios, que surgieron como espacios de reserva con dos compartimentos, uno superior para la exposición de las piezas y provisto de grandes paneles de cristal; otro inferior, como depósito; y los anaqueles, en los que primaba el diseño artístico, sobre lo funcional ${ }^{30}$. También dispusieron de fuelles para las láminas, pedestales de diversas formas y tamaños, paneles para colgar piezas en paredes, estantes colocados directamente en los muros, peanas, trípodes, atriles, centros giratorios, así como maniquíes para los trajes y asientos de descanso ${ }^{31}$. Esta variada tipología vivió su boom en siglo XIX gracias a las nuevas tecnologías de la época, especialmente la fabricación de vidrio plano y delgado que contribuyó a ampliar la diversidad de formas y estructuras y con ello a otorgar estatus a las artes decorativas, a aumentar su demanda, abaratar sus costos, y alcanzar un carácter más comercial. Aspectos que influyeron considerablemente en la

${ }^{27}$ Ibíd.

${ }^{28}$ Robert Organ y Brian Ramer, "Algunas duras verdades”, en Museum Vitrinas 146.2 (París: ICCROM, 1985): 69.

${ }^{29}$ Casas, "El Museo", 44.

${ }^{30}$ Eri Istvén, “Una breve historia de las vitrinas”, en Museum Vitrinas 146.2 (París: ICCROM, 1985): 72-73

31 Virginia Salve y Concha Papí Rodes, "La Exposición Histórico-Natural y Etnográfica de 1893 y su contexto museográfico”, en La Exposición Histórico-Natural y Etnográfica de 1893, editado por Javier Rodrigo del Blanco (Madrid: Ministerio de Educación, Cultura y Deporte): 145-167. 
forma de exhibir las colecciones, pues se pasó del predominio de la apariencia al de su función ${ }^{32}$.

La dotación del mobiliario, para los más de sesenta espacios que albergaron las colecciones expuestas en las Exposiciones Históricas, estuvo a cargo de la comisión técnica que inició sus gestiones en 1891. Por aquella época, se pensaba que su calidad debía estar acorde al estatus del evento, por lo que dicha comisión decidió convocar para su diseño a reconocidos artistas españoles, que debían utilizar preferiblemente pino teñido de negro, guarnecido de vidrios ${ }^{33}$, afín a los usos vigentes en la Europa de los siglos XVI y XVII que, en términos de la historia del mueble, corresponden a reliquias de familia [...] obras maestras de la ebanistería de su tiempo ${ }^{34}$. Sin embargo, los altos costos que acarreaba su ejecución llevó a explorar el mercado extranjero de segunda mano, del que se recibieron dos propuestas, una de Mr. Wiart, que envió modelos, dibujos y planos de vitrinas dotadas de cristales franceses de calidad superior ${ }^{35}$; otra de $\mathrm{Mr}$. Borne, quien ofreció en venta vitrinas negras con vidrios dobles y cerraduras, pero si terminado el evento no se quieren conservar, las vuelve a tomar por el 15\% de su coste, y en alquiler por nueve meses un conjunto de vitrinas procedentes de la Exposición de Moscú. Ofertas que también fueron desechadas por el lujo excesivo y los altos costos. Solo se concretó la adquisición de algunas vitrinas de la segunda ${ }^{36}$.

Se volvió entonces la mirada hacia los expertos nacionales, que debieron ajustarse a "estilos arquitectónicos determinados". Se encargó, entonces, la realización de dibujos a diferentes artistas a fin de seleccionar los más convenientes para levantar los modelos. A enero de 1892 se contó con tres propuestas: la del artista Miguel Velásquez, la del "dorador a mate y bruñido", Aniano Escudero, y los dibujos de José Manuel Laredo y Ordóñez. Estos últimos, que correspondían a los estilos "tomados de la Universidad de Alcalá y de la Capilla de San Juan de los Reyes de Toledo, y á algún otro característico de la arquitectura española del siglo XVI", fueron los que más llamaron la atención de la comisión. No obstante, y teniendo en cuenta que para realizarlos con toda la perfección, que el arte exige, serían necesarios dispendios poco en armonía con el carácter modesto de nuestras Exposiciones y menos aún con los recursos para ellas

\footnotetext{
${ }^{32}$ Istvén, "Una breve", 69.

33 "Exposiciones" (España), AGA, Presidencia de Gobierno, 51/3606, Carpeta 15, f. 30.

${ }^{34}$ István, “Una breve”, 73.

35 “Exposiciones”, f. 31.

${ }^{36}$ Ibíd., ff. 25, 26, 30, 94-96.
} 
disponibles, no era preciso que estuvieran sujetos ála precisión que el arte requiere, porque los convertirían en cosa principal y llenarían superficies que conviene queden libres á fin de que la vista de los objetos expuestos presente los más amplios horizontes posibles, sin que nada impida su examen ${ }^{37}$.

De tal manera que, para ajustarse ámodelos de la mayor sencillez, a la propuesta de Laredo se le introdujeron grandes modificaciones, como la escogencia de una madera que garantizara su larga duración, pero que no fuera tan costosa; y que poseyeran grandes vidrieras para que, terminado el certamen, pasaran a cualquiera de los museos de la ciudad. Definidas las pautas, se abrió concurso público para adjudicar la construcción de 800 metros lineales de estantería y 200 de vitrinas centrales ${ }^{38}$. Mobiliario con el que se esperaba suplir las necesidades de las dos exposiciones. Ruiz de Salces, director de las obras de la Biblioteca y Museos Nacionales y miembro de la comisión técnica, fue el encargado de levantar los planos definitivos y su elaboración quedó en manos de Luis Luesma y Julio Burumburo. El Ministerio de Fomento asumió el costo, que ascendió a 187.331,16 pesetas; y la entrega se fijó entre los meses de junio y septiembre del mismo año ${ }^{39}$. Tener un diseño preestablecido facilitó la ejecución del mobiliario que se requiriera posteriormente.

Para cada nación participante, la ardua labor de instalación empezó por determinar el número, el orden y la ubicación de vitrinas y escaparates que se utilizarían a modo de centrales, aislados o en pares. Si bien es cierto, las vitrinas murales y escaparates centrales ofrecieron cierta unidad de estilo, también convivieron con otro tipo de muebles procedentes de diversas instituciones o traídos directamente por los expositores, como fue el caso de los largos escaparates que combinaban madera y azulejos de las salas de Portugal. Además, la adecuación de los objetos propició distintos acabados de las vitrinas que, terminado el evento, se guardarían a la espera de ser aprovechadas. No obstante, a principios del siglo XX, cuando el Museo Arqueológico Nacional remodeló su montaje, las desechó a pesar de estar bien cerradas con llave, a prueba de polvo y casi herméticas, [...] con buenos vidrios [y con] algo noble y valioso, digno de preservarse, su valor intangible ${ }^{40}$.

\footnotetext{
${ }^{37}$ Ibíd., ff. 94-96, 23-25.

${ }^{38}$ Gaceta de Madrid N. ${ }^{\circ}$ 109, España, abril 18, 1892.

39 "Exposiciones" (España), AGA, ff. 7, 21, 25, 26, 48-52, 67.

${ }^{40}$ George S. Gardner, “¿Qué hacer con las vitrinas antiguas: desecharlas o aprovecharlas?, en Museum Vitrinas 146.2 (París: ICCROM): 76.
} 
"El arte de la instalación”: buen gusto y composición armoniosa Delegados y comisionados tuvieron la difícil tarea de coordinar el montaje de sus instalaciones que, a diferencia de los recintos de las ferias mundiales, ofrecían un menor margen de actuación, dadas las dimensiones y el mobiliario preestablecido. El reglamento estipulaba que para exponer decorosamente los objetos que se presenten, los expositores no tendrían que pagar ni por el derecho a la sala, ni por los trabajos de instalación y decorado. No obstante, quienes desearan embellecer, adornar de algún modo especial la instalación o llevar muebles especiales, lo podrían hacer, previa aprobación del proyecto y asumiendo los gastos, quedando de su propiedad cuanto construyan y presenten ${ }^{41}$. Los responsables, en su mayor parte, integrantes de una élite letrada cosmopolita, muchos de ellos con experiencia en museos, recurrieron al bagaje que les proporcionaba los viajes, las redes de conocimiento y el acceso a literatura especializada ${ }^{42}$.

Para cada nación el diseño de su espacio comenzaba en los quicios de las puertas, que por fuera llevaban su nombre o título de la sección en herrajes niquelados labrados con mucho gusto ${ }^{43}$. Además, y según lo acordado, todas debían formar el pabellón de su portada con la bandera de su Estado y la española, para recordar que la historia de nuestra patria va unida ála de aquéllos desde la época en que el idioma de Cervantes enseñó á unos y otros á amar la religión que redime y el progreso que dignifica al hombre ${ }^{44}$. Al interior, las paredes pintadas de colores claros y el despliegue de un variado repertorio de recursos museográficos fueron una muestra de lo importante que fue para los delegados preparar el adorno de sus respectivas instalaciones, notándose entre ellos el natural afán de revelargusto artístico ${ }^{45}$. La de Guatemala lo hizo, por ejemplo, "tapizando el techo de telas azul y blanca, que, indudablemente, [daban] merecido realce á los valiosos objetos expuestos en las vitrinas y paredes ${ }^{46}$, además de sus ricas telas, exhibidas de forma decorativa, que simulaban mariposas y plantas, todo gracias al trabajo de Juan J. Ortega y el pintor Bermudo" (José Bermudo Mateos). De las salas de

\footnotetext{
${ }^{41}$ El Centenario, Tomo I, Madrid, 1892: 285-292.

${ }^{42}$ El ensayo de Gottfried Semper, Ciencia, industria y arte (1851), o la obra del pintor, y uno de los primeros críticos de arte en España, Ceferino Araujo y Sánchez, Los museos de España (1875).

${ }^{43}$ El Correo Español, Madrid, septiembre 23, 1892, 2.

${ }^{44}$ La Época, Madrid, octubre 8, 1892, 3.

${ }^{45}$ El Heraldo, Madrid, octubre 29, 1892, 1.

${ }^{46}$ Ibíd.
} 
Estados Unidos, dijeron que había sido una excelente idea la de cubrir los cristales con fotografias que se transparentan, y en las que se ven panoramas [...], edificios $y$ cuadros de costumbres de los indios primitivos, o los mapas de sus distintas regiones expuestos en aparatos giratorios ${ }^{47}$.

Estos ejemplos permiten mostrar que, como pasó con el mobiliario, las instalaciones carecieron a nivel global de un guion expositivo uniforme y de una clara organización conceptual. El montaje de los objetos fue asumido más bien de forma intuitiva e improvisada, recurriendo a una variedad de criterios que iban de la mano no solo de los gustos y las modas, sino del tipo de objetos a exponer, buscando sorprender y atraer al observador a través de la importancia otorgada a los componentes estético y didáctico ${ }^{48}$. En este eclecticismo museográfico radica, justamente, la importancia y originalidad de estas Exposiciones, en las que historiadores, arqueólogos, coleccionistas, artistas y arquitecto ${ }^{49}$ lograban conjugar composición armoniosa y decorativismo estético, agrupando objetos para conformar estructuras en forma de abanico, círculo o piramidal, y recurriendo a ambientaciones a través de pinturas y elementos ornamentales ${ }^{50}$. Aspectos que, según las pautas museográficas y de buen gusto dominantes, respondían al arte de la instalación ${ }^{51}$, en el cual el componente estético dejaba de ser exclusivo de los museos de pintura, y hacía presencia en las exhibiciones de objetos arqueológicos e históricos, como es este caso.

Bajo las pautas de agrupación y simetría, formato y tamaño determinaron el "orden" de la composición y, gracias a las disposiciones geométricas, se aprovechaba al máximo el espacio ${ }^{52}$. Aspectos que se vieron reforzados por la vigencia de la teoría del marco, según la cual, el cuadro se comporta como una

${ }^{47}$ El Día, Madrid, octubre 8, 1892, 2.

48 Virginia Salve et ál., "Espacios”, 151.

${ }^{49}$ Costa Rica y España contrataron al pintor y escultor Arturo Mélida Alinari; Nicaragua, al arquitecto Juan Moya; Uruguay, al arquitecto Eduardo Martínez de la Torre y al pintor "señor Ramírez”; Estados Unidos, a los pintores Tomás Campuzano y Cecilio Plá y Gallard y Perú, al escultor Lorenzo Roselló.

${ }^{50}$ Virginia Salve et al, "Espacios... óp. cit., 151.

${ }^{51}$ Término acuñado por G. Brown Goode, delegado de la instalación de Estados Unidos en la Exposición Histórico-Americana, quien tres años más tarde publica el texto Principio de Administración de Museos.

52 Juan Carlos Rico, Montaje de exposiciones: museos, arquitectura, arte (Madrid: Sílex Ediciones, 2007) 37. 
ventana al más allá y el marco como la carpintería de esa ventana ${ }^{53}$. Para el material histórico (libros, documentos y cultura material, en general), se acudió a los esquemas de clasificación temática, cronológica, iconográfica o monográfica. Aunque estas agrupaciones facilitaban por extremo la tarea, así del expositor para reunir los objetos, como de los organizadores de la Exposición para disponerlos, como también de los concurrentes à la misma para verlos y estudiarlos" ${ }^{44}$, en la práctica primó la sucesión de salas, el miedo al vacío y la escenografía del relleno ${ }^{55}$.

\section{Portugal: proyección atlántica e identidad marítima}

España y Portugal han estado siempre conectadas, no sólo por conformar la península ibérica, sino por haberse repartido gran parte del continente americano, hecho que las llevó a ocupar un lugar protagónico en la historia internacional de la Edad Moderna. A principios del siglo XIX, sin embargo, compartían una profunda crisis institucional debida, en gran parte, a la incursión de las tropas napoleónicas y la instauración de un sistema monárquico presidido por José Bonaparte, circunstancia que ocasionó la salida de la corte portuguesa hacia Brasil y la de los Borbones a Francia. Y, tras la independencia de sus antiguas colonias, vieron mermado significativamente su poder imperial, lo que les implicó un llamado de atención en el contexto global finisecular que condicionaba, en palabras de Rina, el principio de nacionalidad a la capacidad de construir imperios coloniales ${ }^{56}$.

Esta conciencia de decadencia, sobre todo de carácter político, despertó una apremiante solidaridad peninsular que avivó el proyecto de conformar un solo Estado. La nueva nación no sería ni portuguesa ni catalana ni castellana sino ibérica, y contemplaba reformas administrativas y territoriales. Idea que a mediados del siglo XIX, aún estaba vigente. Por otra parte, esta crisis se vio alimentada por la "leyenda negra" que estableció una dicotomía entre la Europa meridional, a la que pertenecían España y Portugal, concebida como atrasada, orientalizada y bárbara, por tanto imposibilitada para entrar en la dinámica del progreso, y la septentrional ilustrada. Inmersas, pues, en el paradigma de espacios fronterizos, se fijaron el gran reto de hacer frente a las

53 Tomás Ladrero Caballero, "Enmarcación y museografía en el Museo del Prado en las últimas décadas del siglo XIX”, Librosdelacorte.es, 10.7 (2015): 5.

${ }^{54}$ El Centenario, Tomo II, Madrid, 1892: 140.

55 Juan Carlos Rico, Montaje...óp. cit., 37.

${ }^{56}$ César Rina Simón, "Proyección exterior, hispanoamericanismo y regeneración nacional en la península Ibérica en el siglo XIX”, Historia mexicana Vol. 67, N. ${ }^{\circ} 4$ (2018): 1607-1608. 
amenazas internacionales y contrarrestar este supuesto que las condenaba a la dependencia. Desde esta perspectiva, las celebraciones públicas que tuvieron lugar con ocasión de la conmemoración del cuarto centenario del descubrimiento de América, en 1892, reflejaban anhelos compartidos y sacaron a relucir ese "espíritu peninsular" como el que les había llevado a cumplir una misión histórica: la de explorar el mundo ${ }^{57}$.

En el contexto específico de las Exposiciones Históricas, estas dos naciones buscaron, cada una a su manera, proyectar un nacionalismo expansionista a través de la construcción de imaginarios que daban por sentada su primacía, frente al resto del mundo, en relación con el acontecimiento del descubrimiento del Nuevo Mundo. Imaginarios inmersos en la era del imperialismo, en la que los estados-nacionales se construyeron no sólo desde una introspección historicista sino también sobre un programa de acción exterior, en el cual el prestigio nacional se medía por la capacidad de actuar en la escena internacional, de influir sobre otras naciones o de "civilizar" otros pueblos ${ }^{58}$. Las narrativas a que dieron lugar, como prácticas simbólicas, estaban mediadas por la tensión entre pasado y presente, entre el campo de la experiencia y un horizonte de expectativas. España, lo hizo a partir de su papel protagónico en dicha empresa. Portugal, a través de la proyección de su identidad marítima

Desde esta perspectiva, el país lusitano constituyó su narrativa nacional recurriendo a un pasado idealizado, convertido en el eje central de su configuración como nación moderna. Como hizo España, el recuerdo del descubrimiento fue actualizado como expectativa de ese presente en crisis, representado por la correlación “decadencia-redención”; no obstante, lo hizo con una marca propia, la de su identidad marítima, convirtiendola proyección atlántica en el nódulo de esta narrativa. En 1892, esta proyección encontraba el momento propicio para el despliegue de una profusa liturgia del recuerdo, que se vería reflejada a través de la museografía en las dos salas que le fueron asignadas en el Palacio de Bibliotecas y Museos, en Madrid. En ellas, su repaso al pasado se articulaba no solo como una expresión de un tiempo a emular, sino también como nostalgia de lo perdido, lamento por lo que pudo ser y no fue ${ }^{59}$. De tal manera que, en el tránsito entre la añoranza imperial y el programa colonial moderno, Portugal conjugaba un pasado glorioso con las expectativas imperialistas.

\footnotetext{
${ }^{57}$ Ibíd., 1598-1599.

${ }^{58}$ Ibíd., 1600-1601.

${ }^{59}$ Ibíd., 1600-1603, 1620-1621.
} 
Es así como, en busca de una necesaria regeneración que esperaba tener sus efectos pedagógicos y patrióticos, Portugal aceptó la invitación a participar de los eventos convocados por España y creó en 1891 la "Comisión de la Exposición Colombina”, que empezó a funcionar con tres grupos de trabajo y que más adelante se convirtieron en cuatro secciones: la Marítima, encargada de los descubrimientos y conquistas portuguesas, e integrada por Ramalho Ortigão y Baldaque da Silva; la Bibliográfica y Documental, con la tarea de identificar y publicar la documentación relativa a la época del descubrimiento, conservada en archivos y bibliotecas, y constituida por José Ramos Coelho, Xavier da Cunha y Rafael Eduardo de Azevedo Basto; la Etnografía Americana, única que mantuvo su estructura inicial, cuya misión fue escoger, entre las colecciones públicas y privadas, los objetos provenientes del continente americano, bajo la responsabilidad de Teixeira de Aragão; y, la cuarta, la de Arte Ornamental, comprometida en la recolección de diversos objetos, desde joyas hasta fregaderos de la cocina, cuadros y muebles que ilustraran el pasado artístico de Portugal, con especial atención en los siglos XV a XVII, compuesta por el Conde de Ficalho y los mencionados Ortigão y Teixeira. La Academia de Ciencias operaba como centro de acopio del material proveniente de todos los museos y colecciones del país ${ }^{60}$.

Al interior de esta comisión siempre estaría presente la preocupación por la representación de la identidad marítima de la nación, fundada en su historia de descubrimientos y navegantes. En este sentido, Ortigão sería una figura clave en la promoción de estudios iconográficos relacionados con el paisaje, la cultura y la historia nacional. Su espíritu innovador, su trayectoria en museos y su presencia en diversas exposiciones operaron como factores decisivos a la hora de asumir el liderazgo de la participación portuguesa en España. No obstante, la puesta en práctica de sus ideas fue posible gracias al nombramiento, como decorador oficial de las salas, de Rafael Bordalo Pinheiro, considerado como uno de los más grandes pintores, ceramistas y decoradores de la época. Aspecto que contribuyó a que fuera una de las pocas comisiones que planificó su instalación, antes de llegar a Madrid, cuando se hizo manifiesta la preocupación por el espacio que les sería adjudicado, considerando que de ello dependería la selección de las colecciones y la manera de prestarles la debida atención y

${ }^{60}$ José Miguel Pimenta-Silva, Portugal no IV centenario do descobrimento da América, (Tese de mestrado, História dos Descobrimentos e da Expansão, Universidade de Lisboa, Faculdade de Letras, 2013), 35-37. http://hdl.handle.net/10451/9967, consultado el 18 de diciembre de 2017. 
seguridad $^{61}$. Para resolver tal situación, Ortigão llegó a la capital española a principios de junio y, después de un exhaustivo recorrido por el edificio, del cual señaló que parecía un complicado laberinto, procedió a elegir dos salas de la planta baja, asignada a la Histórico-Americana, ubicadas a mano izquierda, por la entrada del Paseo de Recoletos, que correspondían a los numerales 26 y 27 (Figura N. . 1). La primera de tamaño mediano, con dos ventanas hacia el exterior del edificio; la siguiente, más larga, con ocho ventanas, cuatro de ellas hacia Recoletos, las otras hacia la calle Jorge Juan ${ }^{62}$.

En este punto surge la pregunta sobre el porqué Portugal, como nación europea, no escogió sus salas en el piso asignado a la Histórico-Europea. Parte de la repuesta puede residir en el hecho de que España, como país anfitrión, ya había seleccionado en dicho piso gran parte de sus instalaciones, correspondiendo a la Casa Real y al Museo Arqueológico Nacional las que se encuentran al lado derecho e izquierdo, respectivamente, de la entrada principal de Recoletos. Aun así, desde la perspectiva visual y simbólica, Portugal disponía de un lugar estratégico, frente a la primera sala de la Exposición HistóricoAmericana, ocupada por España (aunque compartida con Dinamarca, Bolivia y Perú), y como remate de la misma. De tal manera que el espectador, al entrar se encontraba con las naciones protagonistas de la expansión atlántica. España estaba desplegada en los dos pisos por hacer parte del Viejo Continente, por tener una relación estrecha con las naciones americanas y por ser la anfitriona. Por todo lo anterior, era natural que, por aquella época, se hablara de que las naciones peninsulares hacían parte de las dos Exposiciones ${ }^{63}$. Se está, pues, nuevamente ante un panorama de historias conectadas entre las naciones peninsulares y de estas con América.

Ahora bien, teniendo certeza sobre la ubicación, tamaño y condición de las salas, Pinheiro empezó a diseñar la instalación teniendo como referentes las instituciones museísticas portuguesas y los elementos decorativos inspirados en el estilo manuelino, y acogió así el gusto dominante á principios del siglo XVI en Portugal, tal como lo expresaba la convocatoria. Gran parte de los preparativos se realizaron en la fábrica de cerámica Caldas da Rainha, propiedad de su familia ${ }^{64}$. El montaje empezó en septiembre, cuando Pinheiro llegó a Madrid junto con Ortigão y Federico Augusto Ribeiro, redactor del periódico Antonio

\footnotetext{
${ }^{61}$ Ibíd., 65.

${ }^{62}$ Ibíd., 65-66.

${ }^{63}$ La Ilustración española y americana, Madrid, febrero 15, 1893, 3.

${ }^{64}$ Pimenta-Silva, "Portugal", 8.
} 
María, y ambos en calidad de auxiliares. Las colecciones arribaron días más tarde, junto con diez marinos de guerra que se alojaron en el cuartel de infantería de marina y estarían al servicio de la comisión ${ }^{65}$.

Con énfasis en la museografía de "inmersión decorativa", que propiciaba la contextualización de objetos a través de su ambientación, se buscaba transportar al visitante a la noción de que Portugal es sinónimo de mar, sensación que se vería reforzada por medio de las alfombras que se extendían entre la entrada de la primera sala y la salida de la segunda, y servían de guía visual al visitante ${ }^{66}$. Como experiencia estética, no se fijaba tanto la atención sobre objetos individuales, sino que, al menos "por unos minutos", invitaba al observador a abandonar el presente ${ }^{67}$. Siguiendo el recorrido, al entrar en la primera sala se dispusieron redes colgadas, banderas y pancartas, vitrinas profusamente adornadas, que contenían documentos, cartografía, joyas, fotografías, antigüedades precolombinas y de numismática, y un sinfín de objetos relacionados con la historia de Portugal, etiquetados con información sobre su procedencia y antigüedad. También se exhibieron cerámicas provenientes de la fábrica Caldas da Rainha, entre las que se encontraba un jarrón ornamental o unos plafones rectangulares con peces, ubicados entre los cableados de la decoración o la réplica de la puerta del monasterio de Madre de Dios que, además de embellecer el espacio, invocaban el espíritu marítimo portugués y sus conquistas, y reforzaban el imaginario de una nación marítima por excelencia (Figura N. ${ }^{\circ} 2$ ). En la otra sala se exponían cuadros y tablas de escuelas flamencas e italianas que le servían para poner de presente los aspectos artísticos y culturales que ligan la nación a la cultura occidental ${ }^{68}$.

\footnotetext{
65 'El Día, Madrid, octubre 16, 1892, 2.

${ }^{66}$ Pimenta-Silva, "Portugal", 70-71.

${ }^{67}$ Cecilia Casas, "El Museo”, 39-40.

${ }^{68}$ Pimenta-Silva, "Portugal", 70.
} 
Figura N. ${ }^{\circ} 2$ : Primera sala de Portugal

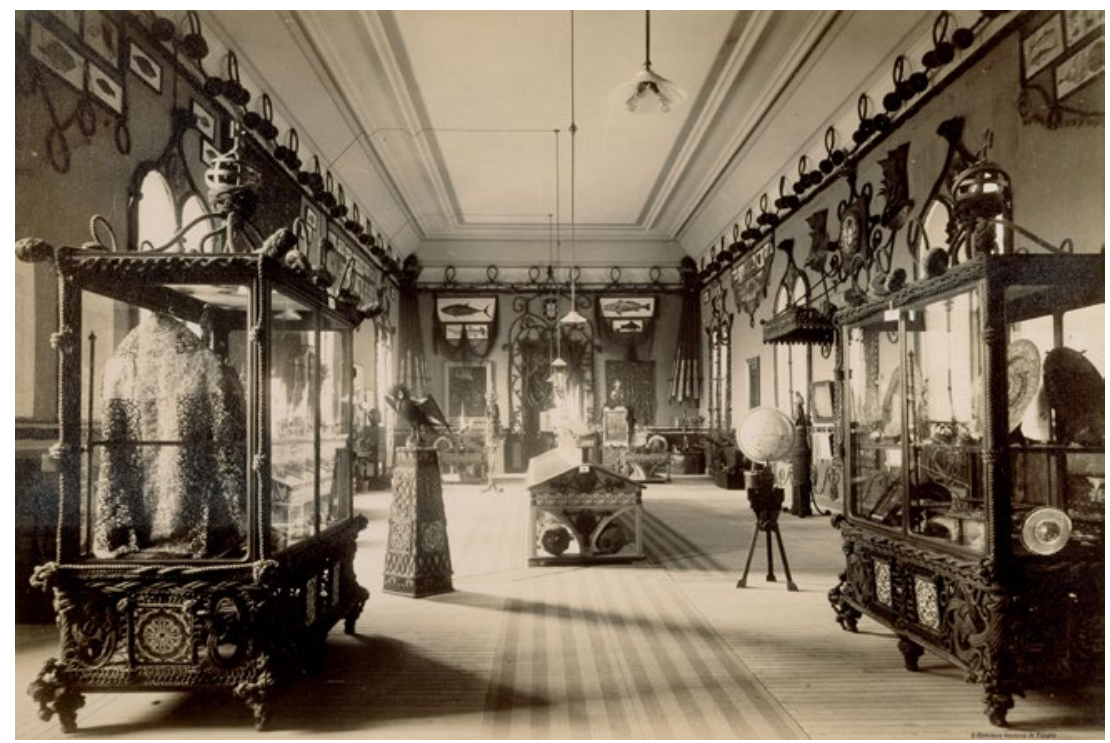

https://www.flickr.com/photos/bibliotecabne/7830098268, 5 de febrero de 2018.

El predominio del "mobiliario de época” de gran calidad, constituido por vitrinas altas y acristaladas, con zócalos decorados con tallas y azulejos del "gusto portugués"; mesas-atril de dos vertientes, con registros acristalados en sus pedestales, o soportes específicos para piezas aisladas, provenientes en su mayoría del Museo Nacional de Arte Antiguo, tenían un doble propósito: servir de sustentáculo a objetos artísticos y constituir ellos mismos un elemento decorativo que exaltara una época, la del reinado de Manuel I. El mobiliario fue concebido como recurso de gran impacto visual que, unido a la disposición de los objetos y a una decoración atrevida y encantadora, llena de simbolismo e historia, contribuía a ensalzar la grandeza de la participación portuguesa ${ }^{69}$. La prensa española señaló que esa instalación brillaba por "el espíritu patriótico" y su ornamentación, y es lo que ustedes llaman un encanto; ha sido la admiración de nacionales y extranjeros [por su] brillo y [su] refinado gusto artístico, y cumplía el gran reto de llevar fuera del país el más extraordinario y minucioso trabajo hecho

${ }^{69}$ Ibíd., 69 y 71. 
a mano, combinado con una dosis de irreverencia e imaginación, y como tal fue elogiado por nacionales y extranjeros, e incluso por otras comisiones ${ }^{70}$.

En 1892 se publicó en Lisboa, bajo la dirección de Joaquín de Araujo, Centenario do descobrimento da América. Memorias da Commissão portuguesa, que recogió las diez memorias, fruto de los preparativos de la comisión: "El Centenario del descubrimiento de América", por Teófilo Braga; "Breve noticia sobre el descubrimiento de América" y "Catálogo de los objetos de arte é industria de los indígenas de América”, por Augusto C. Teixeiro de Aragão; "Estudios sobre navíos portugueses", por Enrique Lopes de Mendouça; "Memoria sobre la residencia de Cristóbal Colón en la isla de la Madera", por Agustín de Ornellas; "Los navíos de Vasco de Gama”, por Juan Braz d’Oliveira; "El descubrimiento del Brasil", por Pedro Álvarez Cabral; "Memoria de A. A.", por Baldaque da Silva; y “Carta del rey D. Manuel al Rey Católico”, por Próspero Peragallo ${ }^{71}$.

\section{Colombia: "reliquias de grandes naciones" que han degenerado ${ }^{72}$}

En la primera mitad del siglo XIX, y tras los procesos de independencia, las élites de las recién conformadas naciones hispanoamericanas centraron sus esfuerzos en la creación de una imagen nacional diferenciadora y basada en los esquemas universales de nacionalismo, progreso y modernización. En este contexto, el hispanismo surgió, a ambos lados del Atlántico, como una corriente ideológica que buscaba restablecer los lazos entre España y sus antiguas colonias. La celebración del IV Centenario se presentaba, entonces, como ocasión propicia para promover una "comunidad espiritual" basada en la existencia de una "raza transatlántica”, compartida por los pueblos que en un momento de su historia habían pertenecido a la Corona española ${ }^{73}$. En tierras americanas se tradujo en un sólido movimiento político y cultural, de sesgo conservador, que buscó articular sus postulados con los proyectos nacionales.

${ }^{70}$ El Día, Madrid, noviembre 10, 1892: 2.

${ }^{71}$ Fidel Fita Colomé, "Portugal en la Exposición histórica de Madrid”, Boletín de la Real Academia de la Historia, tomo 21 (Madrid: 1892): 534.

72 Algunos de los aspectos abordados en este apartado han sido trabajados por Carmen Cecilia Muñoz en ¿Cómo representar los orígenes de una nación moderna y civilizada? Colombia en la Exposición Histórico-Americana (Madrid, 1892) (Cali: Programa Editorial de la Universidad del Valle, 2012).

${ }^{73}$ Ricardo Pérez Montfort, Hispanismo y Falangé Los sueños imperiales de la derecha española (México: FCE, 1992), 6-15. 
Precisamente, la invitación a participar en la Exposición HistóricoAmericana le llegó a Colombia en pleno apogeo del período conocido como "la Regeneración" (1880-1930), definido por la revalorización de la época colonial, y que estimuló un sentimiento de deuda hacia la "madre patria", considerada como la proveedora de los pilares de la construcción nacional (idioma, religión e historia comunes) ${ }^{74}$. Con este telón de fondo, el gobierno acogió con entusiasmo la convocatoria y consiguió acudir por primera vez, y de manera oficial, a una exposición de carácter internacional, tras varios intentos fallidos en concurrir a las famosas ferias mundiales decimonónicas ${ }^{75}$. Ante el llamado a enviar objetos que permitieran reconstruir "el estado de civilización" de sus antiguos pobladores a la llegada de los españoles y sirvieran para dar idea del origen y progreso de su "relativa cultura", las voluntades se encaminaron a la recolección de "antigüedades indígenas" de diversa índole. La selección y catalogación de este material estuvo permeada por el contexto ideológico del hispanismo y sus diversas aristas.

Siguiendo a Quijada, en la construcción de las naciones hispanoamericanas decimonónicas se diferencian dos fases: la "nación cívica" y la "nación civilizada". En la primera, Colombia recurrió a los indígenas contemporáneos y sus antepasados como estandarte de la lucha independentista, pero sólo como recurso retórico, pues no fueron incorporados en la historia nacional. Décadas más tarde, perdida la fe en el proyecto liberal y sus instituciones, tomó ventaja la idea de que "civilizar" implicaba eliminar todos aquellos obstáculos que impedían el proceso civilizatorio y, en esta fase las poblaciones indígenas que no hablaran el idioma español y no se hubieran convertido al cristianismo fueron asociadas a la barbarie $\mathrm{o}$ al salvajismo, a diferencia de las evangelizadas y sujetas al gobierno republicano, que las entraron a formar parte de la categoría de ciudadanos $^{76}$.

Se supone que todo estaría imbricado al historiar sus pasados, aspecto clave en la configuración del linaje patrio, en el que se esperaba que las culturas originarias adquirieran el carácter de "ancestros", para lograr establecer un continuum. Sin embargo, la elite criolla en Colombia optó por declarar al

\footnotetext{
${ }^{74}$ Carlos Rama, Historia de las relaciones culturales entre España y la América Latina. Siglo XIX (México, FCE, 1982), 103-105.

${ }^{75}$ Véase Frédéric Martínez, ¿Cómo representar a Colombia? De las exposiciones universales a la Exposición del Centenario, 1851-1910”, en Museo, memoria y nación: misión de los museos nacionales para los ciudadanos del futuro (Bogotá: Museo Nacional de Colombia, 2000).

${ }^{76}$ Quijada, "Ancestros", 37-38.
} 
hecho colombino como momento fundacional de la nación, relegando a sus antepasados aborígenes a la prehistoria, a pesar de que sus artefactos permitían rastrear los orígenes de una nación moderna y civilizada, más allá de la perspectiva hispanista. Circunstancia que se vio reforzada por la noción de catastrofismo, que consideraba, a los hacedores de tan magníficas piezas, desaparecidos, por diversas circunstancias, desde antes del proceso colonizador, de tal manera que sus descendientes no guardaban ninguna relación con aquellos $^{77}$. En este sentido, Restrepo Tirado señala que los quimbayas, uno de estos pueblos, aunque pertenecían a una raza fuerte, aguerrida y agrícola que había logrado manipular el noble metal con una maestría que no alcanzaron a igualar las naciones más adelantadas de América [...] por mucho que trabaje la imaginación no es posible comprender cómo podían aquellos bárbaros, sin conocer los reactivos químicos [formar] esas cuentecitas minúsculas que parecen gotitas de oro soldadas unas a otras ${ }^{78}$. Concepción que tendrá fuertes implicaciones en la construcción de un imaginario nacional.

Con estas premisas, el gobierno inició los preparativos para hacer presencia en las tres exposiciones centenaristas, concentrando al final todos los recursos y los esfuerzos en la de Madrid. El proceso comenzó con la creación, en 1891, de la "Comisión de las Exposiciones de Madrid y Chicago", conformada por Salvador Camacho Roldán, Felipe F. Paúl, Vicente Restrepo, Gonzalo Ramos Ruiz y Carlos Martínez Silva ${ }^{79}$, que, meses más tarde, se reconfiguró. La nueva comisión estuvo dirigida por Martínez Silva, director del periódico El Telegrama; e integrada por Carlos Calderón, como vicepresidente; Julio Arboleda, en calidad de secretario y, como vocales, los reconocidos anticuarios Vicente Restrepo - también ministro de Relaciones Exteriores-, Gonzalo Ramos Ruiz, Nicolás J. Casas, Arturo de Cambil y Julio E. Pérez. El Ministerio de Fomento autorizó, para su funcionamiento, un crédito extraordinario por 100.000 pesos, una suma excesiva para la época. Al respecto, Martínez Silva señaló que puede que así sea; pero á los que de tal modo discurren nos permitimos recordarles que cuando llega para una familia pobre el caso del matrimonio de una hija, hay necesidad de empeñar hasta las joyitas de los abuelos para salir del trance con cierto decoro. Y este es el caso en que Colombia se encuentra al presente ${ }^{80}$.

\footnotetext{
${ }^{77}$ Earle, "Monumentos y museos", 41.

${ }^{78}$ Ernesto Restrepo Tirado, Los quimbayas: al décimo octavo Congreso internacional de americanistas que reunirá en Londres en mayo de 1912 (Bogotá: Imprenta nacional, 1912), 62.

${ }^{79}$ El Correo Nacional, Bogotá, Septiembre 1. ${ }^{\circ}, 1891,3$.

${ }^{80}$ El Telegrama, Bogotá, Noviembre 30, 1891, 2.
} 
Aunque la comisión empezó a funcionar con cuatro subcomisiones: historia, desarrollo intelectual, protohistoria y minería, al poco tiempo las dos primeras asumieron los preparativos para Chicago y las otras dos, los de Madrid. Estas últimas iniciaron los trabajos en enero de 1892 bajo la orientación de Ramos Ruiz, quien, esperando excitar el patriotismo, hizo un llamado especial a los dueños de antigüedades, a través de cartas y avisos de prensa, con el fin de que enviaran ya fuera en alquiler, donación, préstamo o compra, objetos tales como momias y cráneos indígenas, fósiles o huesos de animales que sirvan de comprobante á los descubrimientos arqueológicos de aquellas remotas edades; así como colecciones de antigüedades indígenas y, sin excepción todos los objetos que concurran á dar idea del grado de adelanto alcanzado por los aborígenes al tiempo de la conquista, bajo sus aspectos etnográfico, arqueológico, industrial y artístico; además de todos los documentos, códices, planos, cartas, dibujos y obras históricas originales de todas clases, asímanuscritas como impresas, existentes en el país y escritas desde el descubrimiento de América hasta mediados del siglo XVII ${ }^{81}$.

La renuncia de Ramos Ruiz obligó a reestructurar la subcomisión, ya denominada de protohistoria, bajo la tutela de Vicente Restrepo. En vista de que el tiempo apremiaba y el primer llamado no produjo los resultados esperados, el gobierno optó por comprar, alquilar o solicitar el préstamo de colecciones de antigüedades. Por compra estuvo una muy valiosa de objetos de oro, encontrada recientemente, conocida como el tesoro de los quimbayas; en préstamo, las colecciones de los vocales Nicolás J. Casas y Vicente Restrepo, y la de Julio Cuervo Márquez ${ }^{82}$; por su parte, el Museo Nacional tuvo una escasa participación, dadas las precarias condiciones en que se encontraba. Al final, las más de dos mil piezas recolectadas acarrearon a una ardua labor de clasificación y descripción, que estuvo acompañada de la toma de fotografías y la elaboración de un catálogo. Trabajo que constituyó un hecho sin precedentes en la historia de la arqueología colombiana.

El catálogo, elaborado por Vicente Restrepo y su hijo, el arqueólogo Ernesto Restrepo Tirado, estuvo acorde con los lineamientos del evolucionismo que proponía una clasificación jerarquizada, basada en el asentamiento geográfico y la técnica de los artefactos, variables que permitían ubicar a una sociedad en una determinada escala de civilización. Siguiendo estos criterios, el primer lugar lo ocupaba "la nación” chibcha que, desde mediados del siglo XIX, había concentrado la atención de especialistas que intentaban demostrar que esta

${ }^{81}$ El Correo Nacional, Bogotá, enero 12, 1892, 3.

${ }^{82}$ El Orden, Bogotá, febrero 27, 1892, 2. 
cultura, al igual que los aztecas o los incas, había logrado un alto grado de civilización gracias a haber ocupado tierras altas, consideradas como las más convenientes para el desarrollo intelectual; a la calidad de sus vestigios; el haber practicado la momificación y, suponer que poseía calendario. A renglón seguido, estaban las denominadas tribus, en el siguiente orden: quimbayas; las que habían ocupado los territorios de Antioquia, Cauca, Tolima y Panamá; y, por último, las inscripciones y grabados en piedra ${ }^{83}$. Clasificación que expresaba, así fuera de forma retórica, el interés por establecer el linaje de la nación.

Las 23 cajas precedentes de Bogotá y Manizales, que contenían antigüedades y demás material, salieron para España en el mes de julio bajo la responsabilidad de Isaac Arias Argáez, quien fue recibido en Madrid por la delegación colombiana integrada por Julio Betancourt, ministro plenipotenciario de Colombia en España; José T. Gaibrois, encargado de negocios y jefe interino de la Comisión; y los delegados Ernesto Restrepo Tirado, José Moreno y Fernández de Lara; además de Carlos Umaña, Bendix Koppel y Manuel Santamaría Hurtado, propietarios de colecciones. En principio, Restrepo y Gaibrois se ocuparán del montaje de la sala, pero, al tener que viajar el primero a Huelva, el segundo asume el papel de comisionado especial junto a José Moreno, Isaac Arias y los artistas españoles Lafourcade y Malato que trabajaron día y noche para ejecutar obras de decoración que contribuyan eficazmente al éxito general de la sección ${ }^{84} \mathrm{y}$ a sacar con lucimiento á Colombia y lo lograron ${ }^{85}$, contando con cuarenta mil pesos oro, suma estipulada por la Junta para tal fin ${ }^{86}$. La tardanza en la llegada de los objetos hizo que el 12 de noviembre, día de la inauguración, la instalación aún no estaba lista.

En el quicio de la puerta de entrada de la sala asignada, la número 21, se ubicó la lujosa bandera elaborada en seda del país, enviada por Rafael Núñez, el presidente de la nación y destinada á señalar el lugar de Colombia ${ }^{87}$. Respecto al mobiliario, se dispuso de diez armarios adosados y adornados con escudos de armas de ciudades de Colombia, cada uno de los cuales contaba con tres

${ }^{83}$ Véase Catálogo especial de la República de Colombia: Exposición Histórico-Americana (Bogotá: Sucesores de Rivadeneira, 1892).

${ }^{84}$ El Telegrama, Bogotá, febrero 14, 1892, 2.

${ }^{85}$ El Telegrama, Bogotá, enero 16, 1893, 2.

${ }^{86}$ (Bogotá), AGN, Ministerio de Relaciones Exteriores, Legación de Colombia en España, Carpeta 120.

${ }^{87}$ AGN., Ministerio de Relaciones Exteriores, Tomo 120, correspondencia (Bogotá, 13 de julio de 1892). 
divisiones, las de arriba y abajo con piezas de cerámica, y la central, forrada en peluche azul oscuro, con las de orfebrería de las denominadas tribus y algunas de origen quimbaya, destacándose la de Vicente Restrepo que lespareciómagníficay muy rica á los conocedores ${ }^{88}$. En la parte superior, y entre los armarios, numerosas fotografías y reproducciones de la obra Kultur und industrie sudamcrikanischer volker, publicada en Berlín por W. Reiss y B. Koppel, en 1889. Muebles protegidos con vidrio contendrán la momia hallada en Tópaga [que] la abriga una manta de algodón y tiene á sus pies el caracol sagrado envuelto en algodón y cubierto por un burdo tejido; la obra del botánico Mutis; publicaciones sobre arqueología; y manuscritos relativos al país. Las piezas más pequeñas ocuparían un armario de seis tablones, forrado en peluche rojo ${ }^{89}$. Para el gusto de la época, el salón, aunque no era de los más grandes, estaba arreglado con arte y elegancia $a^{90} \mathrm{y}$, sin que me ciegue el patriotismo [...] al encerrar tales tesoros, parece colosal estuche en que se exponen los regalos de boda de una princesa de Las Mil y una noches ${ }^{91}$, señalará la escritora colombiana Soledad Acosta de Samper (Figura N. ${ }^{\circ}$ 3).

Figura No. 3: Sala de Colombia

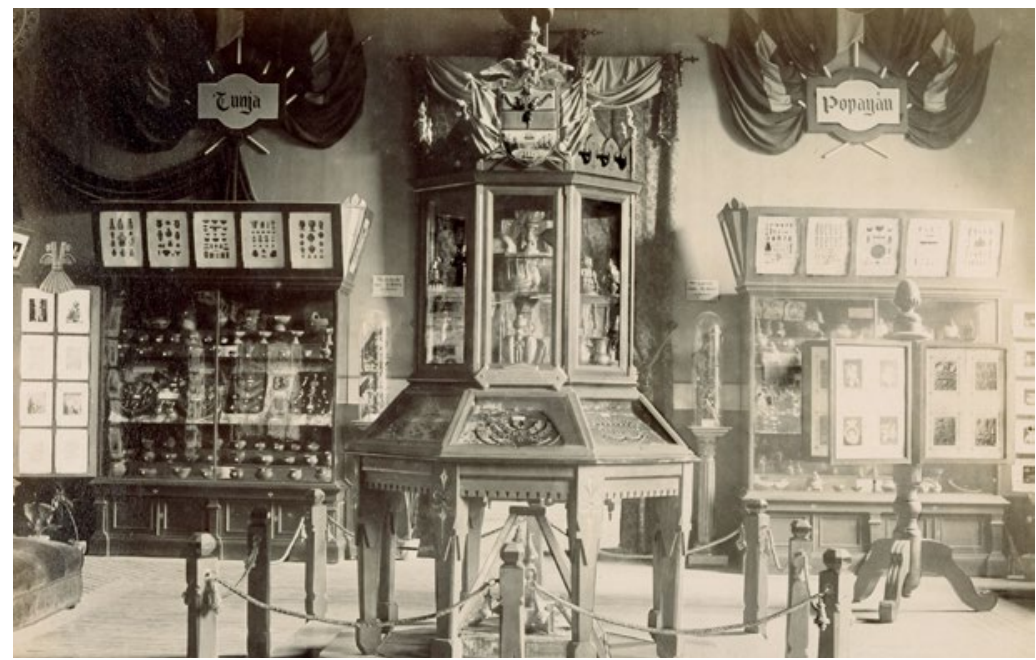

https://www.flickr.com/photos/bibliotecabne/7830101026, 20 de enero de 2018.

\footnotetext{
${ }^{88}$ El Telegrama, Bogotá, enero 16, 1893: 2.

${ }^{89}$ El Telegrama, Bogotá, febrero 14, 1893: 2.

${ }^{90}$ El Telegrama, Bogotá, enero 16, 1893: 2.

${ }^{91}$ El Correo Nacional, Bogotá, abril 8, 1892: 2.
} 
Tras el discurso museográfico desplegado por los comisionados colombianos estaba un concepto expositivo que guardó estrecha relación con la manera en que la elite criolla pretendía construir la imagen de la nación. La distribución y ubicación de las colecciones permite inferir aspectos de la matriz discursiva que guio el montaje. En él, Colombia se exhibía como un "estuche de tesoros" de grandes culturas del pasado, pero desaparecidas, dispuestas a ser regaladas u ofrecidas al mejor postor. Para el primer caso, estaba la vitrina octogonal ubicada en el centro de la sala y defendida por una cadena, que contenía las piezas del "tesoro de los quimbayas" que, terminada la Exposición, se regalaron a la reina regente María Cristina, en agradecimiento por el papel que desempeñó en el laudo arbitral entre Colombia y Venezuela y por el empeño puesto por Julio Betancourt, ministro plenipotenciario de Colombia en España, y con destino al Museo Arqueológico Nacional ${ }^{92}$.

Ese "mueble bellísimo de cristales coronado por el busto de Colón y á los lados ... los escudos de armas de Colombia y España” ${ }^{93}$ simboliza las bases de la identidad nacional: 1492 como momento fundacional y, ligado a él, el hispanismo como derrotero de un imaginario de nación civilizada. Representación que marcó, de forma tajante, la ruptura con su pasado ancestral que, al recibirlo, la "madre patria" quedó maravillada. A su alrededor, las estanterías exhibieron el panorama más completo, conocido hasta el momento, de las culturas originarias que habitaron el territorio nacional, y cuyas creaciones allí expuestas comenzaron un viaje de no retorno, pues los coleccionistas particulares autorizaron a Restrepo Tirado para que dispusiera libremente de la mayor parte de ellas, en el mercado estadounidense, a donde viajaron para ser vendidas, tras participar en la Exposición Universal Colombina, celebrada en Chicago en julio de $1893^{94}$.

\section{A manera de conclusión}

A partir del análisis de la matriz discursiva que subyace tras el diseño y el montaje de las instalaciones de Portugal y Colombia en las Exposiciones Históricas que tuvieron lugar en Madrid, en 1892, con motivo de la celebración del denominado, por ese entonces, descubrimiento de América o del Nuevo Mundo, es posible hallar puntos de encuentro y diferencias en relación con

\footnotetext{
92 Véase Pablo Gamboa Hinestrosa, El tesoro de los quimbayas: historia, identidad y patrimonio (Bogotá: Planeta, 2002);, El tesoro quimbaya, eds. Alicia Perea, Ana Verde Casanova y Andrés Gutiérrez Usillos (Madrid: Consejo Superior de Investigaciones Científicas (CSIC) y Ministerio de Educación, Cultura y Deporte, 2016).

${ }^{93}$ El Telegrama, Bogotá, enero 16, 1893, 2.

${ }^{94}$ Véase Carmen Cecilia Muñoz, ¿Cómo representar?”
} 
la construcción de imaginarios nacionales, a uno y otro lado del Atlántico, en un contexto finisecular conectado, en este caso, a través de un hecho puntual, la conmemoración a la que se ha hecho referencia. El acercamiento evidenció un afán, presente tanto en Portugal como en Colombia, por inscribirse en el concierto de las naciones modernas mediante el reconocimiento de un momento fundacional que no solo le diera sustento a un pasado glorioso sino que las proyectara hacia el futuro.

Portugal, ante la conciencia de la decadencia peninsular, recurrirá en sus narrativas a un pasado idealizado bajo la perspectiva de una identidad marítima que actualizada como expectativa de un presente en crisis y convertida en proyección atlántica. Su participación en las Exposiciones Históricas constituye una oportunidad de regeneración que buscó legitimar y proyectar su contribución a la historia moderna como potencia marítima. El diseño planificado de su instalación, en el que confluyeron mobiliario, "arte manuelino", piezas, diseño y decoración, fue una muestra del interés por recuperar este imaginario, por conjugar un pasado glorioso con las expectativas imperialistas.

Colombia, por su parte, construyó una narrativa nacional que privilegiaba el legado hispánico sobre los grados de civilización alcanzados por los antiguos pobladores de sus territorios, aunque sus artefactos demostrasen un alto nivel en el manejo de la técnica. Circunstancias que llevaron al gobierno colombiano, no solo a poner todo su empeño en los preparativos para acudir a Madrid, sino a desprenderse de gran parte de su patrimonio arqueológico, que inició un viaje de no retorno. Las colecciones arqueológicas exhibidas y su distribución en el espacio de exposición asignado mostraron por primera vez, a los ojos del mundo, el panorama más completo - hasta ese entonces conocido- de sus antiguas culturas, cuya incorporación simbólica a la historia nacional solo ocurrió a principios del siglo XX, a la par con los primeros esbozos de legislación proteccionista, como reflejo de la necesidad de proveer al país de unos ancestros. Tarea que aún sigue vigente.

\section{Referencias bibliográficas}

\section{Fuentes primarias}

\section{Manuscritas}

Archivo General de la Administración, España (AGA)

- Presidencia de Gobierno, Exposiciones, 51/3606, Carpeta 15. 
- Asuntos Exteriores, Legajo 286.

Archivo General de la Nación, Colombia (AGN)

- Ministerio de Relaciones Exteriores, Tomo 120, correspondencia.

- Ministerio de Relaciones Exteriores, Diplomática y Consular, Legación de Colombia en España.

\section{Periódicos y revistas}

El Centenario (Madrid), 1892

El Correo Español (Madrid), 1892

El Correo Nacional (Bogotá), 1891

El Día (Madrid), 1892

El Heraldo (Madrid), 1892

El País (Madrid), 1892

El Telegrama (Bogotá), 1891

España y América (Madrid), 1892

Gaceta de Madrid (España), 1891

La Ilustración Española y Americana (Madrid), 1893

La Época (Madrid), 1892

\section{Audiovisuales}

Biblioteca Nacional, España (BNE):

https://www.flickr.com/photos/bibliotecabne/7830101026

https://www.flickr.com/photos/bibliotecabne/7830098268

http://hemerotecadigital.bne.es/issue.vm?id=0002320318

\section{Fuentes secundarias}

Benedict, Burton. "International Exhibitions and National Identity". Anthropology Today Vol: 7, N. 3 (Jun., 1991), http://www.jstor.org/stable/3032792, consultado el 3 de febrero de 2018.

Bertrand, Romain. "Historia global, historias conectadas: ¿un giro historiográfico?”. Prohistoria: historia, politicas de la historia, N. ${ }^{\circ} 24$ (2015): 3-20.

Burke, Peter. Qué es la historia cultural. Barcelona: Paidós, 2006.

Earle, Rebecca. "Monumentos y museos: la nacionalización del pasado precolombino en la Hispanoamérica decimonónica. En Galerías del progreso: museos, exposiciones y cultura visual en América Latina, editado por Beatriz González Stephan y Jens Andermann. Rosario: Beatriz Viterbo Editora, 2006, 27-56.

Casas Desantes, Cecilia."El Museo Cerralbo, una colección personal, una instalación de su tiempo 1893-1922”. En Museos de ayer. Museografias históricas en Europa. Madrid: Ministerio de Educación, Cultura y Deporte, 2017, 24-52.

Catálogo especial de la República de Colombia: Exposición Histórico-Americana. Bogotá: Sucesores de Rivadeneira, 1892. 
Chakrabarty, Dispesh. Al margen de Europa. Pensamiento postcolonial y diferencia histórica. Barcelona: Tusquets Editores, 2008.

Fita Colomé, Fidel. "Portugal en la Exposición histórica de Madrid”. Boletín de la Real Academia de la Historia, tomo 21 (1892): 534.

Freestone, Robert y Marco Amati, (Eds.). Exhibitions and the development of modern planning culture. London: Ashgate Publishing Ltd., 2014.

Frisch, Michael H. "El prisma del pasado en el cambio del siglo: uso de las ferias mundiales. La exposición panamericana de 1901 como estudio de un caso concreto”. Studia Historica. Historia Contemporánea, N. ${ }^{\circ} 16$ (Salamanca, 1998): 123-136.

Gardner, George S. ¿QQué hacer con las vitrinas antiguas: desecharlas o aprovecharlas?. Museum Vitrinas Vol. 146, N. ${ }^{\circ} 2$ (París: ICCROM, 1985): 74-78.

Hobsbawm, Eric. "Introducción: la invención de la tradición”. En La invención de la tradición. Barcelona: Crítica, 2002, 7-21.

Istvén, Eri. "Breve historia de las vitrinas". Museum Vitrinas Vol. 146, N. 2 (París: ICCROM, 1985): 71-74.

Ladrero Caballero, Tomás. "Enmarcación y museografía en el Museo del Prado en las últimas décadas del siglo XIX”. Librosdelacorte.es, Vol. 10, N. 7 (2015): 1-22.

Martínez, Frédéric. ¿Cómo representar a Colombia? De las exposiciones universales a la Exposición del Centenario, 1851-1910”. En Museo, memoria y nación: Misión de los museos nacionales para los ciudadanos del futuro. Bogotá: Museo Nacional de Colombia, 2000, 316-333.

Muñoz Burbano, Carmen. ¿Cómo representar los orígenes de una nación moderna y civilizada? Colombia en la Exposición Histórico-Americana (Madrid, 1892). Cali:Programa Editorial Universidad del Valle, 2012.

Norambuena, Carmen. "Imaginarios nacionales latinoamericanos en el siglo XIX". Historia Unisinos, Vol. 10, N. 2 (2006): 121-132.

Organ, Robert y Brian Ramer. "Algunas duras verdades”. Museum Vitrinas Vol. 146, N. ${ }^{\circ} 2$ (París: ICCROM 1985): 68-71.

Pérez Montfort, Ricardo. Hispanismo y Falange. Los sueños imperiales de la derecha española. México: FCE, 1992.

Pimenta-Silva, José Miguel. "Portugal no IV centenario do descobrimento da América”, Tese de mestrado, História dos Descobrimentos e da Expansão, Universidade de Lisboa, Faculdade de Letras, 2013. http://hdl.handle.net/10451/9967, consultado el 18 de diciembre de 2017.

Quijada, Mónica. "Ancestros, ciudadanos, piezas de museo. Francisco P. Moreno y la articulación del indígena en la construcción nacional argentina (siglo XIX)". Estudios Interdisciplinarios de América Latina y el Caribe Vol. IX, N. 2 (1998): 21-46.

Rama, Carlos. Historia de las relaciones culturales entre España y la América Latina. Siglo XIX. México: FCE, 1982.

Restrepo Tirado, Ernesto. Los quimbayas: al décimo octavo Congreso Internacional de Americanistas que reunirá en Londres en mayo de 1912. Bogotá: Imprenta Nacional, 1912. 
Rico, Juan Carlos. Manual práctico de museología, museografía y técnicas expositivas. Madrid: Sílex Ediciones, 2006.

Rico, Juan Carlos. Montaje de exposiciones: museos, arquitectura, arte. Madrid: Sílex Ediciones, 2007.

Rina Simón, César. "Proyección exterior, hispanoamericanismo y regeneración nacional en la península Ibérica en el siglo XIX”. Historia mexicana Vol. 67, N. 4 (2018): 1607-1608.

Salve, Virginia et ál. "Espacios y objetos a través del tiempo: Museografía histórica de las salas del Museo Arqueológico Nacional”. Boletín del Museo Arqueológico Nacional, N. ${ }^{\circ} 32$ (2014): 60-66.

Salve, Virginia y Concha Papí Rodes. "La Exposición Histórico-Natural y Etnográfica de 1893 y su contexto museográfico". En La Exposición Histórico-Natural y Etnográfica de 1893, editado por Javier Rodrigo del Blanco. Madrid: Ministerio de Educación, Cultura y Deporte, 145-167.

Smith Anthony y Olaf Bernárdez. Nacionalismo: teoría, ideología, historia. Madrid: Alianza editorial, 2004.

White, Hayden. Metahistoria: la imaginación histórica en la Europa del siglo XIX. México: Fondo de Cultura Económica, 1992. 